\title{
Field Measurement and Study on Overburden Fracture and Surface Subsidence Law of Solid Filling Mining under Buildings
}

\author{
Zhiyong Fu, ${ }^{1}$ Lujie Zhou ${ }^{D},{ }^{2,3}$ Kai Yu, ${ }^{3}$ Wanzhen $\mathrm{Li}^{4}{ }^{4}$ and $\mathrm{Hu} \mathrm{Chen}^{5}$ \\ ${ }^{1}$ College of Mining, Liaoning Technical University, Fuxin 123000, Liaoning Province, China \\ ${ }^{2}$ State Key Laboratory of Mining Disaster Prevention and Control Co-founded By Shandong \\ Province and the Ministry of Science and Technology, Shandong University of Science and Technology, Qingdao 266590, China \\ ${ }^{3}$ College of Safety and Environmental Engineering, Shandong University of Science and Technology, Qingdao 266590, China \\ ${ }^{4}$ College of Energy and Mining Engineering, Shandong University of Science and Technology, Qingdao 266590, China \\ ${ }^{5}$ Tiandi (Changzhou) Automation Co., Ltd., Changzhou 213000, China
}

Correspondence should be addressed to Lujie Zhou; 13969891661@163.com

Received 23 September 2021; Accepted 25 October 2021; Published 9 December 2021

Academic Editor: Pengfei Wang

Copyright (c) 2021 Zhiyong Fu et al. This is an open access article distributed under the Creative Commons Attribution License, which permits unrestricted use, distribution, and reproduction in any medium, provided the original work is properly cited.

In order to predict the surface subsidence scientifically in solid filling mining, it is necessary to establish a complete subsidence prediction model and parameter system according to the evolution law of overburden structure and strata movement characteristics. Mine pressure monitoring and borehole peeping show that the overburden in solid filling mining is mainly a bending zone with relatively complete layered structure, and the overburden only develops a certain height of fault zone near the roof, without collapse. The results show that the surface subsidence pattern of solid filling mining can still be described by probability integral model, and the parameter system of the surface subsidence prediction model based on "equivalent mining height" is further discussed. Finally, the prediction model of surface subsidence established in this paper is applied to an engineering example, and good results are achieved.

\section{Introduction}

In recent years, with the development of coal mining science and technology, filling mining has become one of the important technical ways to solve the problem of coal pressure under buildings, water bodies, railways, and confined water bodies [1-5]. Compared with the traditional caving method, the overburden of filling mining can maintain a certain degree of integrity and continuity and will not trigger greater deformation and destruction, thus reducing and slowing down the surface subsidence over stope [6-9]. The roof can be controlled in filling mining by filling the mining area with solid waste such as gangue, which can not only effectively control surface subsidence and improve the coal recovery rate but also rationally utilize solid waste $[10-12]$. The waste is not transported and stored, which is beneficial to reduce the cost and obviously reduce the surface deformation, thus avoiding the impact on the surface environment [13-15].
In order to study the law of rock pressure appearance and the law of overlying strata change under the condition of solid waste filling mining in mines, the surface movement and deformation of backfilling mining are predicted and analyzed through the field measurement of surface subsidence in backfilling mining, and then, the control effect of backfilling mining on overlying strata and surface is evaluated [16-19]. By making full use of the existing engineering conditions of a mine in the eastern mining area of China, the monitoring system of the mining hydraulic support system was established to analyze the variation law of working resistance of filling hydraulic support with the advancing of working face. The monitoring system of surrounding rock deformation and stress was established to study the law of rock pressure appearing in two roadways. The real-time monitoring system of borehole peeping for the stress in the filling body of gob and the crack development in the roof of gob is established to get the movement law of overlying 
strata after filling with solid waste in gob. At the same time, the observation station of surface subsidence is arranged to analyze the measured data of surface subsidence $[20,21]$, so as to provide data support for the prediction of surface movement and deformation model.

\section{Overview of Working Face}

2.1. Mining Face Location. According to the actual conditions of a gangue solid filling mining area, 8103 filling face is arranged in the mining area. 8103 filling face is located under village, town, and other structures. The coal seam of 8103 filling face is 8 coal seam. The upper and lower comparisons of the working face are shown in Figure 1.

2.2. Coal Seam and Roof and Floor Conditions. The coal seam of 8103 filling face is $8 \#$ coal seam, which belongs to complex structure coal seam. The inclination angle of coal seam is $7-10^{\circ}$, the average inclination angle is $8.5^{\circ}$, the bulk density of coal is $1.49 \mathrm{t} / \mathrm{m} 3$, the average thickness of coal seam is $3.7 \mathrm{~m}$, the mining face elevation is from $-730 \mathrm{~m}$ to $-680 \mathrm{~m}$, and the corresponding surface elevation is about $+19 \mathrm{~m}$. Coal seam contains 1-2 layers of intercalated rock with thickness of 0.1 $0.2 \mathrm{~m}$, mainly carbonaceous mudstone and mudstone. The roof and floor of 8103 filling face are shown in Figure 2.

2.3. Mining Face Parameters. The reserves of 8103 filling face are about $220,000 t$, the mining strike is $128 \mathrm{~m}$ long, the inclined mining width is $120 \mathrm{~m}$, and the recovery rate is $95 \%$. The actual mining-filling ratio of 8103 working face is $1: 1$, which means 1 ton of coal is mined with 1 ton of gangue filled. This working face adopts a new type of comprehensive mechanized gangue filling mining system, which can ensure full contact between the filling body and roof, that is, filling underjointed roof quantity $h_{q}=0$. According to the compression test of waste rock in laboratory, the compression ratio of waste filling body is $\eta=15 \%$.

\section{Stope Pressure Monitoring}

In order to reveal the characteristics and regularities of rock pressure in filling face and mining roadway and the movement law of overburden strata in stope, on-site monitoring of rock pressure in 8103 filling face during mining process is carried out. The contents include stress monitoring of mining hydraulic support system, stress monitoring of surrounding rock affected by mining, stress monitoring of the filling body in gob, and borehole peek monitoring of roof crack development in overlying strata of gob.

\subsection{Monitoring and Analysis of Support of Hydraulic Support in Coal Mining}

3.1.1. Layout Scheme of Monitoring Equipment. In order to study the variation of working resistance of hydraulic support in 8103 filling face with the advance of the working face, a monitoring instrument of working resistance is arranged along the hydraulic support in the working face, as shown in Figure 3.

3.1.2. Monitoring Results and Analysis. Through the analysis of monitoring results of working resistance of backfilling support in 8103 working face, the measured curve of working resistance distribution is shown in Figures 4-7.

In the solid filling mining process of 8103 working face, the average initial support force is between $6600 \mathrm{KN}$ and $7000 \mathrm{KN}$, which is little different from the average working resistance of the support $7200 \mathrm{KN}$ to $7800 \mathrm{KN}$. When the working face is pushed to $15 \mathrm{~m}, 35 \mathrm{~m}$, and $60 \mathrm{~m}$ positions, respectively, the average working resistance of the support increases slightly to $7400 \mathrm{KN}, 7700 \mathrm{KN}$, and $7500 \mathrm{KN}$, which are not up to the rated working resistance of the hydraulic support $8800 \mathrm{KN}$, and there is no sharp increase of working resistance, which indicates that the working resistance of the support increases sharply. There are no initial and periodic weighting phenomena in the mining process of filling coal face. The hydraulic support of filling coal mining effectively controls the roof subsidence before filling.

\subsection{Monitoring and Analysis of Surrounding Rock Deformation in the Working Face}

3.2.1. Layout Scheme of Monitoring Equipment in Roadways of the Working Face. The layout equipment of two roadways in the working face is mainly to observe the rock pressure appearance, advance abutment pressure, and surrounding rock deformation of the two roadways. There are three stations in the two lanes, each of which is $10 \mathrm{~m}$ in length, as shown in Figure 8.

Layout of mine pressure monitoring instruments in two roadways: in order to observe the movement of roof and floor and the approximation of two sides of roadway in 8103 filling face, the longitudinal force of bolt (cable), and the displacement of deep surrounding rock, six monitoring points of roadway surface displacement, twelve multipoint displacement meters, and twelve bolt (cable) stress monitors are arranged in the two roadways, which are distributed evenly in each station to monitor various data.

Layout of monitoring equipment for advance abutment pressure: in order to monitor the advance abutment pressure of two roadways in the mining process of the working face, six supporting pillars are installed in each roadway of the working face, and pressure monitors are arranged. The advanced pressure monitor is arranged at the positions of $20 \mathrm{~m}, 80 \mathrm{~m}$, and $140 \mathrm{~m}$ from each roadway, respectively. Before the start of mining, six advanced pressure monitors are installed, which will not move along with the advance of the working face and will be removed when the working face reaches the position where they were installed.

3.2.2. Monitoring Results and Analysis. Based on the analysis of the actual measurement of the advance stress of the coal body in two roadways of 8103 working face, the measured curve of the advance monomer working resistance in the 


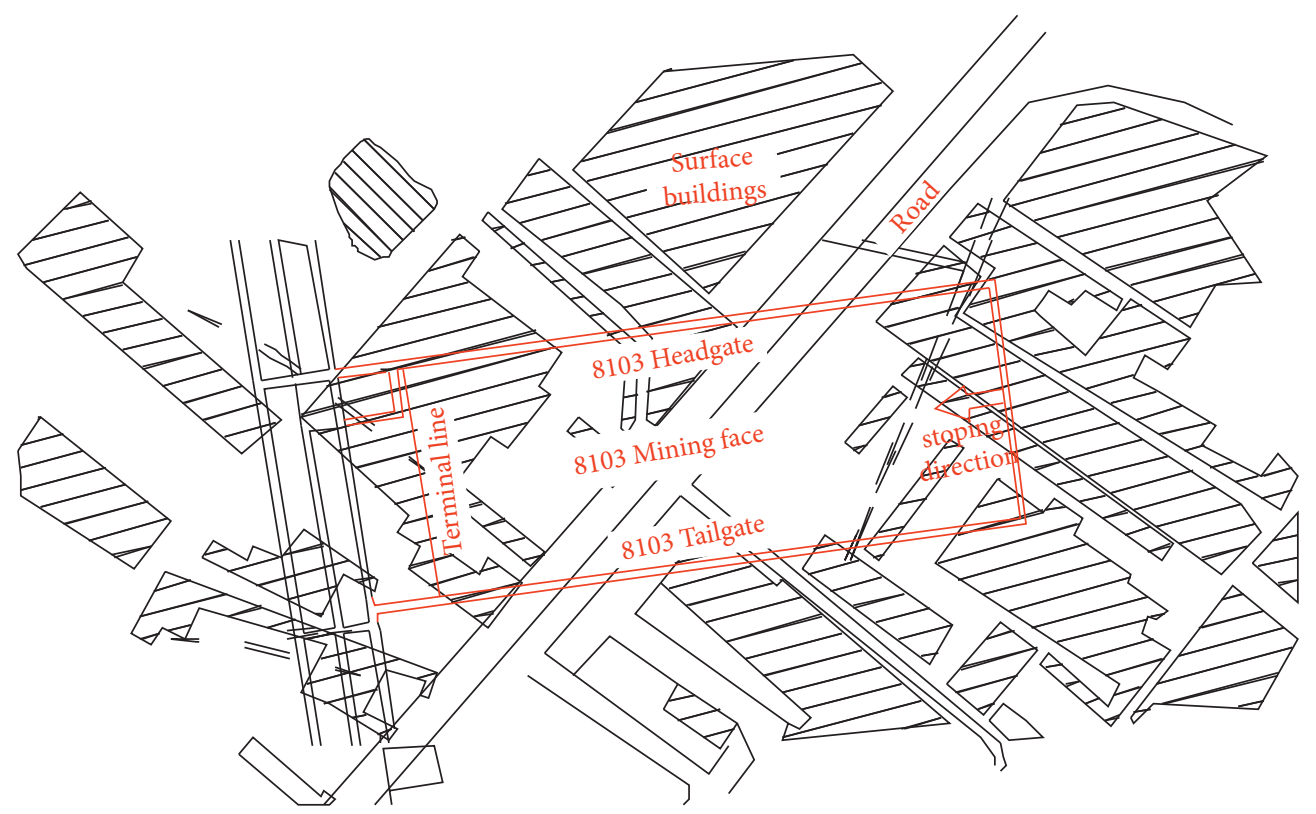

FIGURE 1: Layout of roadway in 8103 backfilling mining face and comparison between upper and lower wells.

\begin{tabular}{|c|c|c|c|}
\hline Lithology & Formation & Roof and floor & Thickness (m) \\
\hline 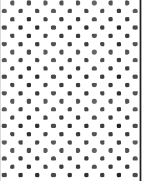 & $\begin{array}{l}\text { Off-white } \\
\text { medium } \\
\text { stone } \\
\text { and fine } \\
\text { stone }\end{array}$ & Main roof & 4.5 \\
\hline & $\begin{array}{l}\text { Dark gray } \\
\text { sandy mud- } \\
\text { stone }\end{array}$ & $\begin{array}{l}\text { Immediate } \\
\text { roof }\end{array}$ & 0.35 \\
\hline & Coal & $8 \#$ coal & 3.7 \\
\hline 然 & $\begin{array}{l}\text { Dark grey } \\
\text { siltstone }\end{array}$ & $\begin{array}{l}\text { Immediate } \\
\text { floor }\end{array}$ & 1.5 \\
\hline$\therefore$ & $\begin{array}{l}\text { Off-white fine } \\
\text { stone }\end{array}$ & Main floor & 15.2 \\
\hline
\end{tabular}

FIGURE 2: Roof and floor condition of 8103 working face.

gangue haulage roadway is obtained, as shown in Figure 9. The measured curve of the advance monomer working resistance in the coal haulage roadway, the measured curve of the anchor force in the coal haulage roadway, and the measured curve of the anchor force in the gangue haulage roadway are similar to those shown in Figure 9.

Based on the analysis of the measured deformation of surrounding rock in two roadways of 8103 working face, the measured curve of surrounding rock deformation in coal haulage roadway of 8103 filling face is obtained, as shown in Figure 10 . At about $18 \mathrm{~m}$ away from the working face, the closeness of the roof and the floor and the closeness speed of two sides of rock mass are the fastest, the closeness speed of the roof and the floor is about $5.5 \mathrm{~m} / \mathrm{d}$, and the closeness speed of rock mass is about $6.4 \mathrm{~mm} / \mathrm{d}$; the closer to the working face it is, the faster the displacement of the roof and floor is. The larger the proximity is, the smaller the change is. It can be divided into slow growth stage, rapid growth stage, and stable stage. The change trend of working resistance of advanced monomer in gangue roadway is basically the same. In the same position, the displacement of the roof and the floor is greater than that of two sides of rock mass.

\subsection{Monitoring and Analysis of Internal Stress in the Filling Body}

3.3.1. Layout Scheme of Monitoring Equipment in the Filling Body. In order to monitor the pressure change of the filling body in 8103 filling face under the action of roof, 25 filling body stress monitors were installed in the filling body. The instrument is arranged in five rows, five in each row and symmetrically arranged. The distance from the roadway side of 8103 coal haulage roadway is $5 \mathrm{~m}, 30 \mathrm{~m}$, and $60 \mathrm{~m}$, respectively. When the self-cutting eye is pushed to $10 \mathrm{~m}$, the first row of equipment is installed. When the working face is pushed to $30 \mathrm{~m}, 50 \mathrm{~m}, 80 \mathrm{~m}$, and $100 \mathrm{~m}$, the other rows of equipment are installed, respectively, as shown in Figure 11.

3.3.2. Analysis of Stress Change in the Filling Body. The stress monitoring and analysis of the filling body in the working face is carried out by using the stress monitor. The change of the stress with the working advancing distance is shown in Figure 12. 


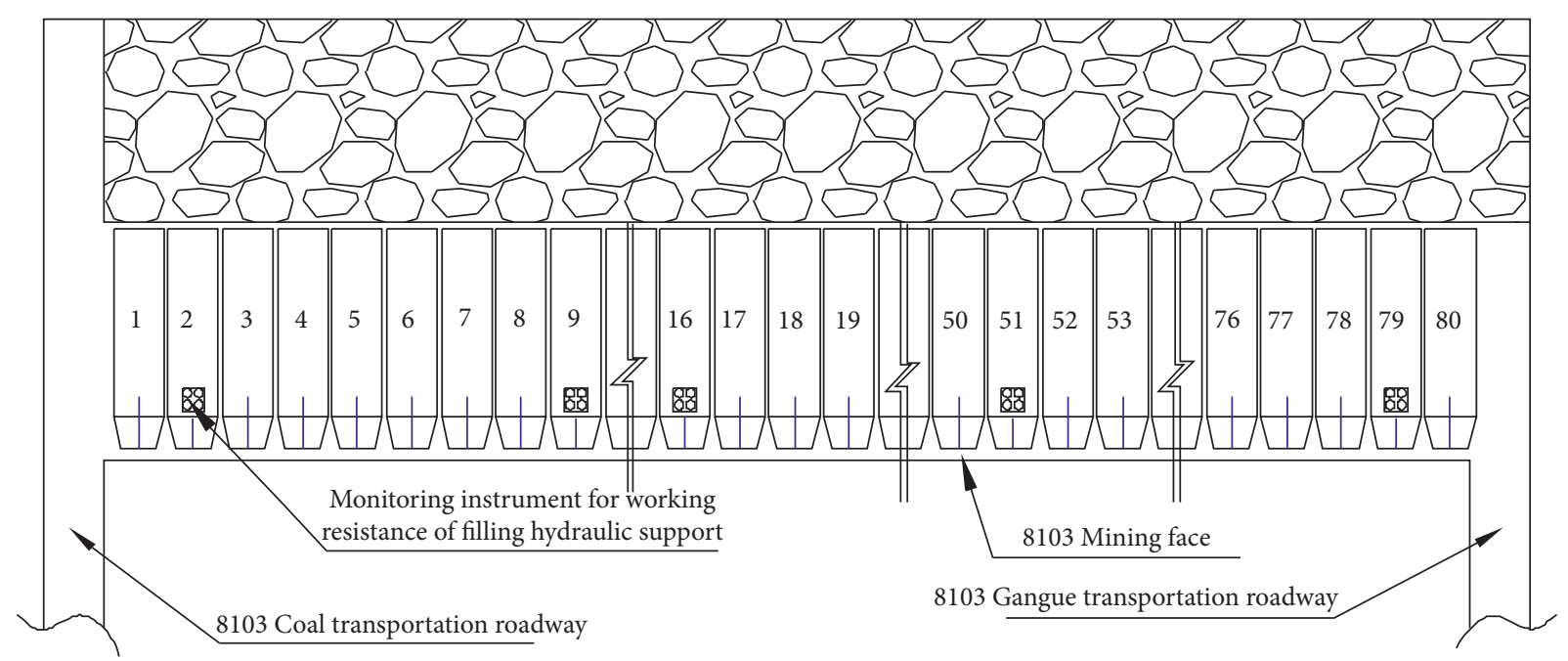

FIGURE 3: Layout of pressure monitoring equipment for filling hydraulic support.

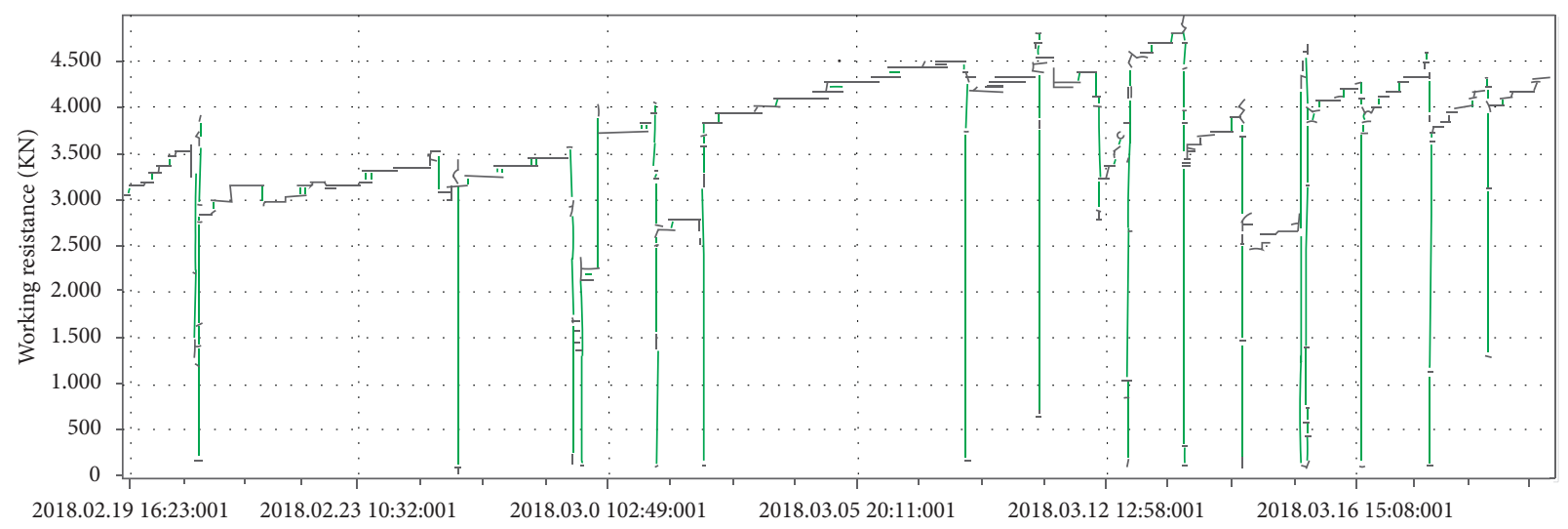

FIGURE 4: 1 \#online monitoring of working resistance of extension Support (2018.02.19-2018.03.16).

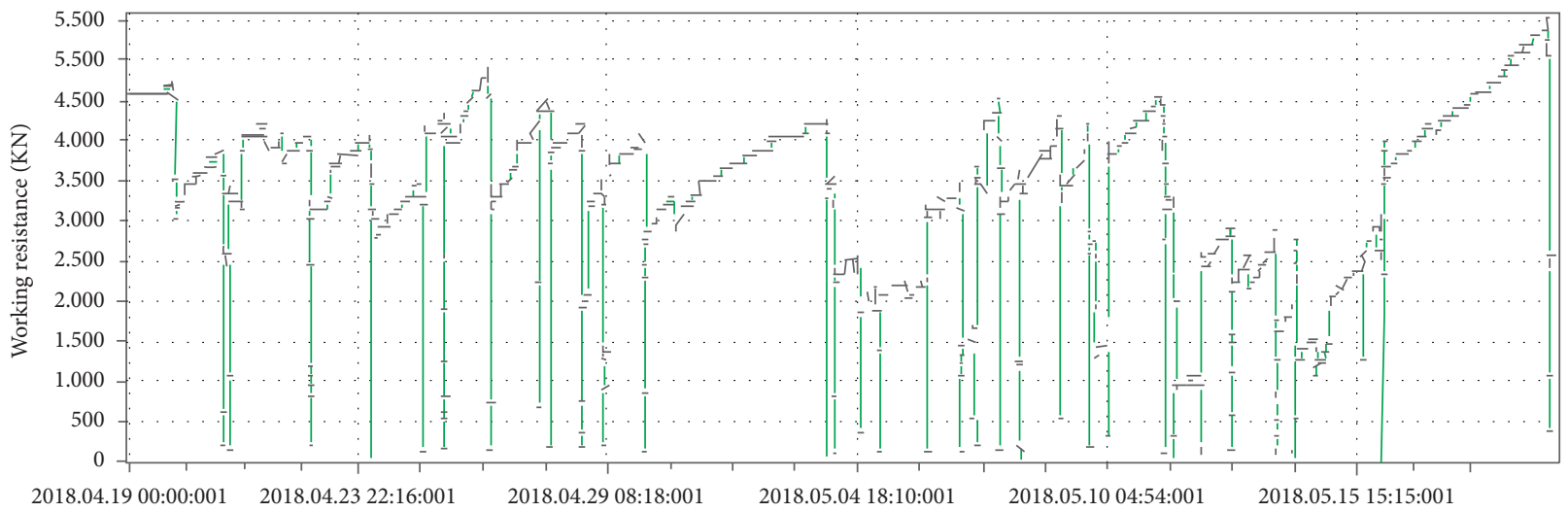

FIGURE 5: 1 \#online monitoring of working resistance of extension support (2018.04.19-2018.05.15).

From the analysis, we can see that, with the advancing of the working face, the stress variation law of the filling body can be divided into three stages: initial stress zone $(0-15 \mathrm{~m}$ from working face), stress increasing zone (15-33m), and stress stable zone (after $33 \mathrm{~m}$ ), which are consistent with the variation law of roof subsidence with advancing distance of the working face.
Within the initial stress range of $0-15 \mathrm{~m}$, the internal stress of the filling body varies between 1.6 and $2 \mathrm{MPa}$, and there is almost no stress increase, which indicates that the roof bending subsidence in the initial stress area after filling is small.

In the stress increasing area of $15-33 \mathrm{~m}$, the stress inside the filling body increases gradually, but the growth rate is 


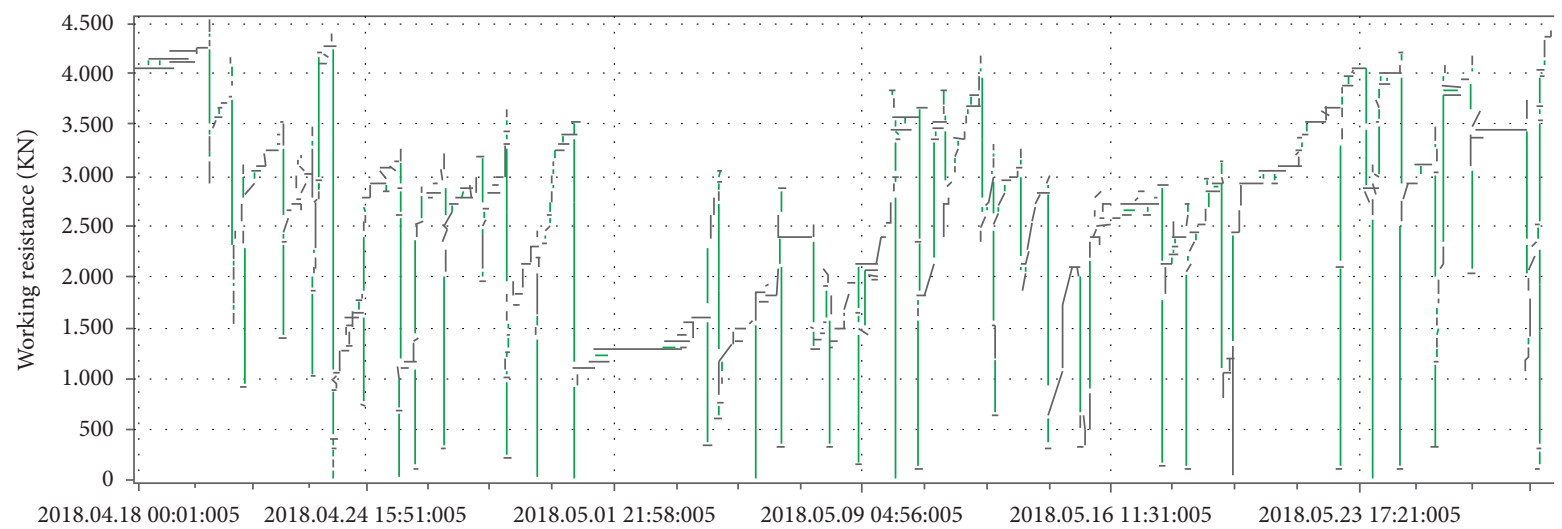

Figure 6: 5 \#online monitoring of working resistance of extension support (2018.04.18-2018.05.23).

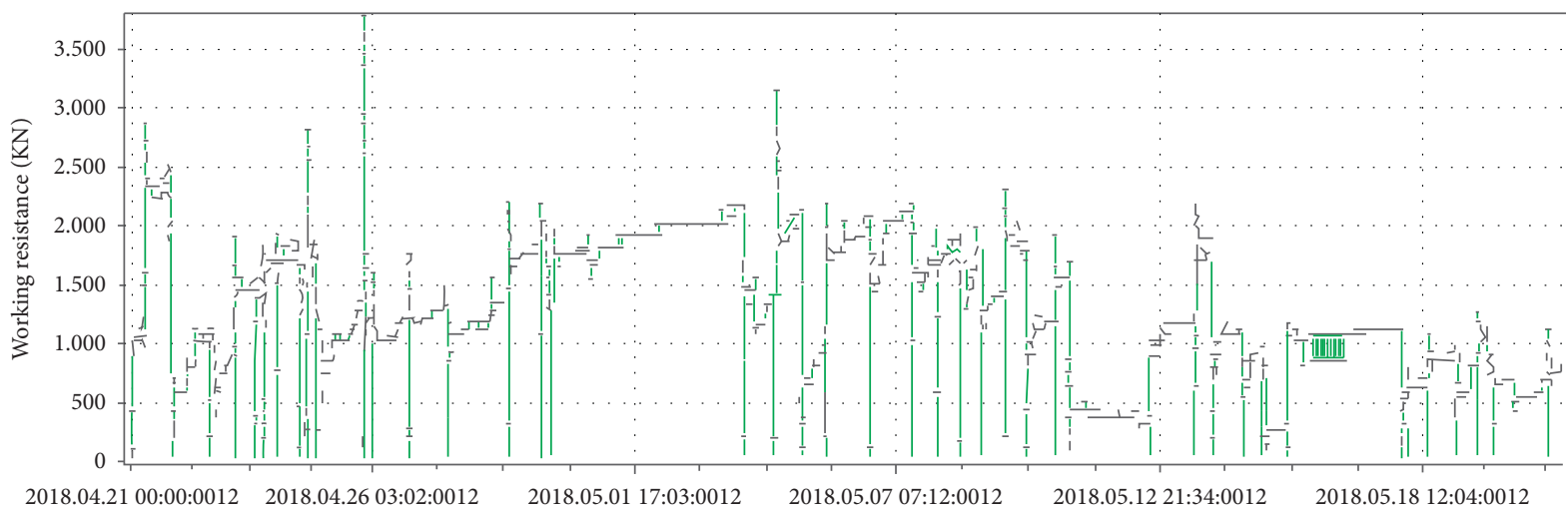

FIGURE 7: 12 \#online monitoring of working resistance of extension support (2018.04.21-2018.05.18).



\footnotetext{
$\square-$ Advanced pressure monitor

Multi-point displacement meter

- Surface displacement monitoring point

A- Bolt (cable) stress monitor
}

FIGURE 8: Layout of monitoring equipment in working face roadway. 


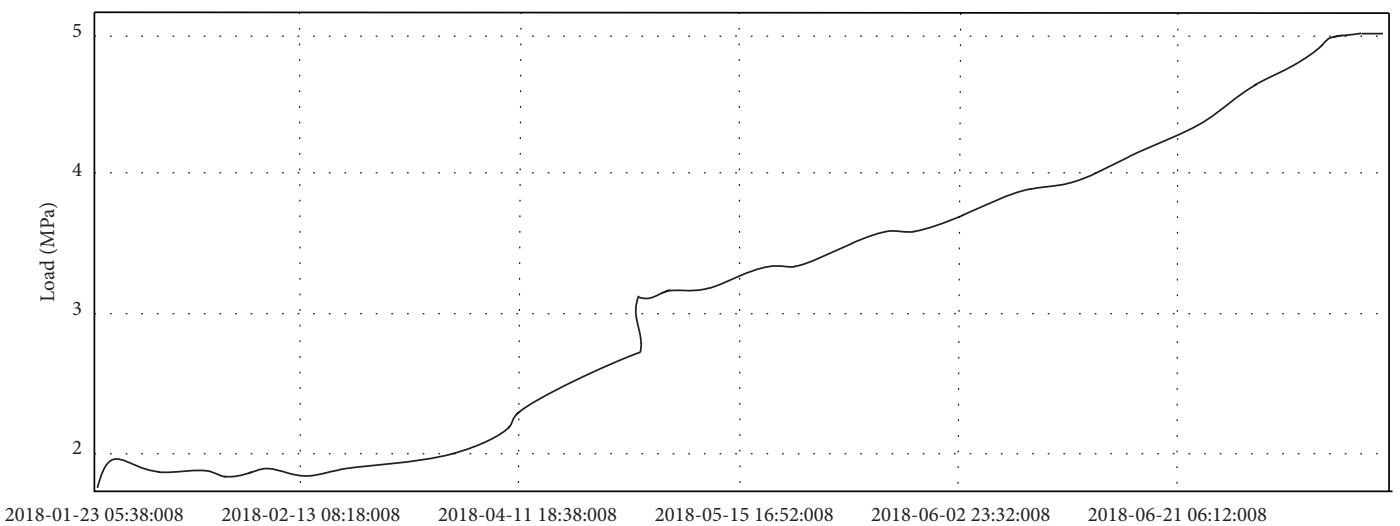

FIGURE 9: Measuring curve of working resistance of advanced unit in gangue transport roadway of the working face.

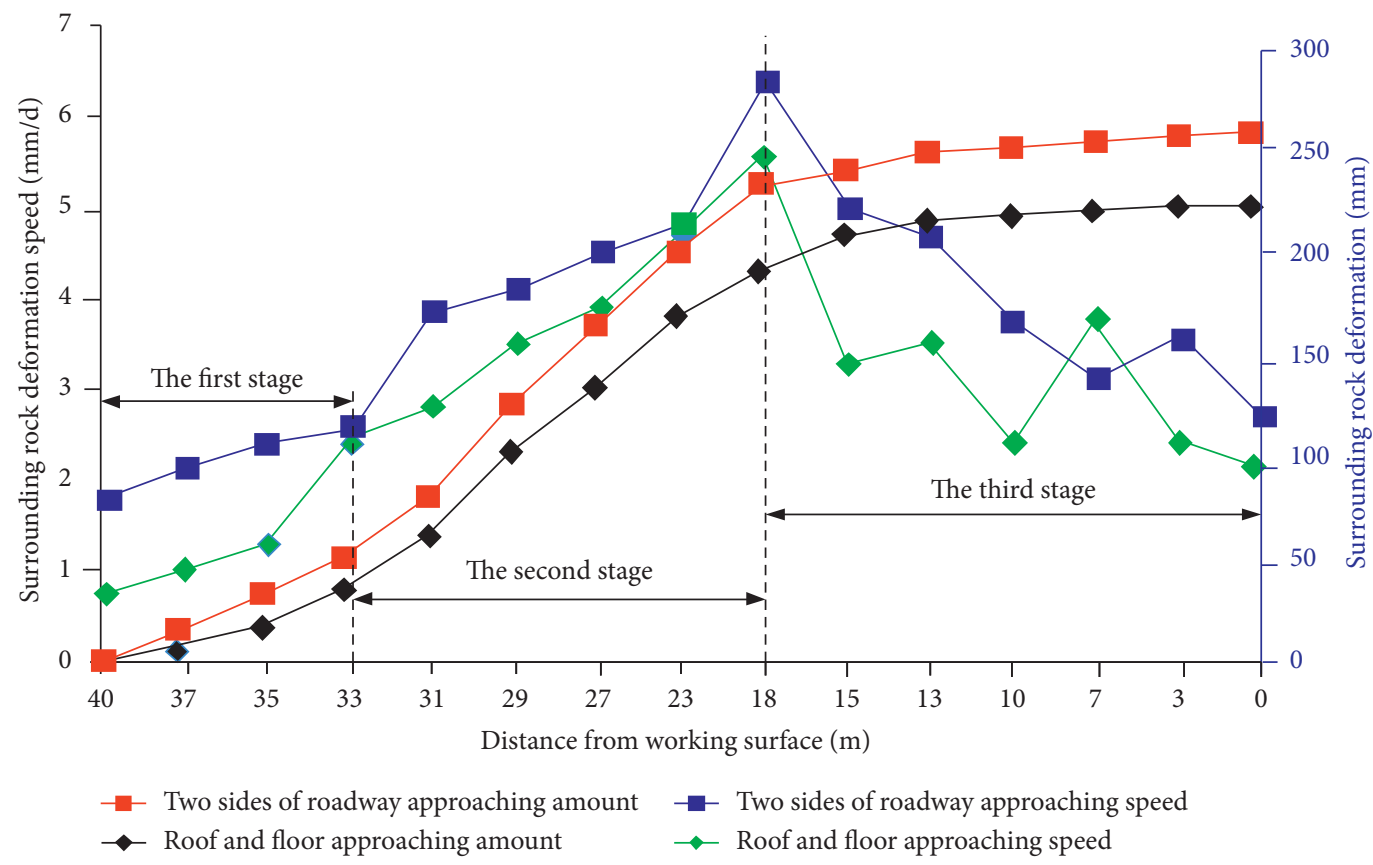

FIGURE 10: Surrounding rock deformation measured curve of coal transportation roadway in the working face.

slow, which indicates that the roof of the goaf is gradually bent and subsided under the action of overlying strata, and the filling body is gradually compacted.

After $33 \mathrm{~m}$ away from the working face, with the advancing of the working face, the internal stress of the filling body gradually stabilizes, with the maximum value reaching $12 \mathrm{MPa}$, which is close to the original rock stress, indicating that the overall bending subsidence of the overburden strata has become stable under the support of the filling body at this time.

\subsection{Monitoring and Analysis of Roof Fracture Development Characteristics}

3.4.1. Design Scheme of Drilling Position. In order to observe the movement, deformation, and fissure development of overlying strata under the condition of fully mechanized mining with solid filling, a series of boreholes need to be laid in 8103 working face according to the layout of filling mining face in a mine. The height and width of cracks in boreholes are regularly monitored by the selected borehole television imager (as shown in Figure 13), and then, the movement law of overlying strata and the movement law of overlying strata cracks in filling mining are obtained.

According to the location of 8103 working face, inclined observation boreholes are planned to be laid in the air passage and slide passage of the working face. The boreholes in the two roadways are symmetrically arranged, and the specific location of the boreholes is shown in Figure 14. The vertical height upward of the 1\# and 2\# borehole is about 20 meters. Observed boreholes dip into the basic top with an inclination of $15^{\circ}$.

The development of roof fissures in goaf is detected by borehole television. The detection results are shown in Figures 15 and 16. 




Figure 11: Layout of the filling stress monitor.



FIGURE 12: Measured curve of stress change of the filling body.
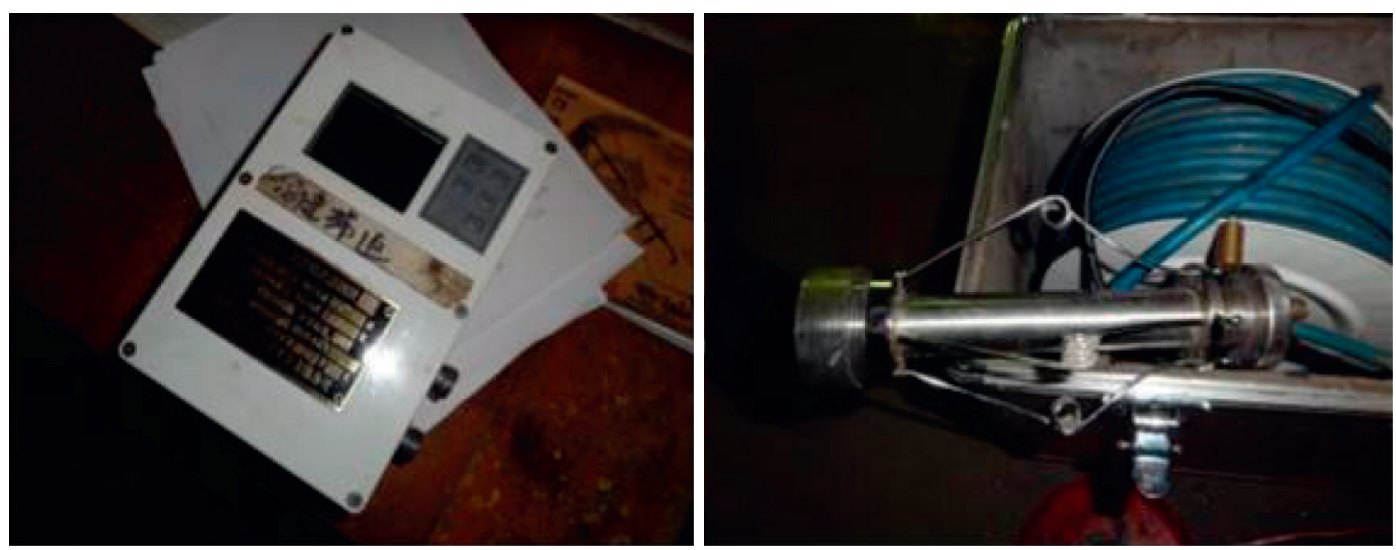

Figure 13: Borehole television imager. 




FIGURE 14: Drilling position design drawing.
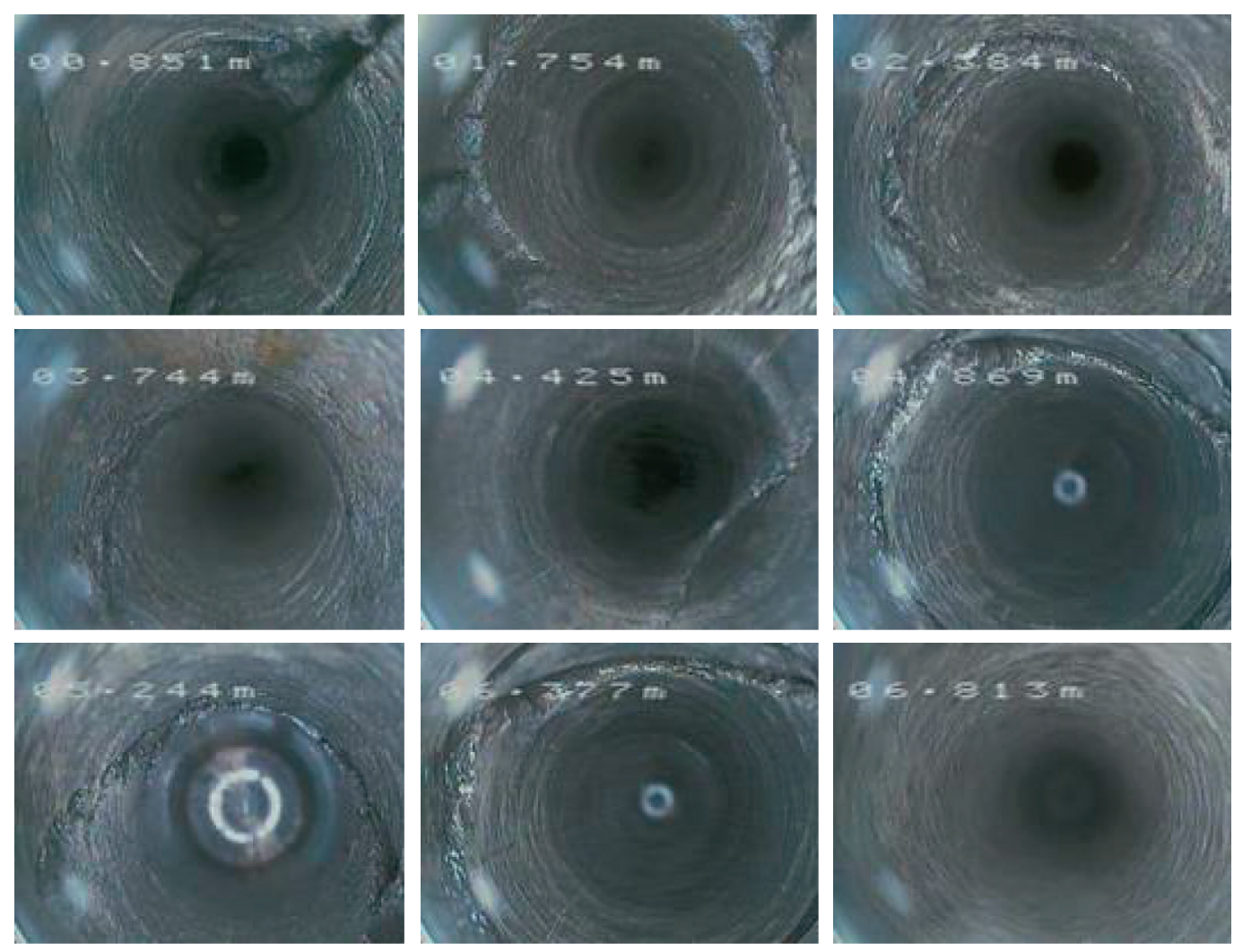

FIGURE 15: The result of borehole TV detection.

According to the results of borehole detection, with the advancing of working face, the overburden strata rupture in gob develops spatially from shallow to deep; the shallow is mainly in the form of rupture, and the deep is mainly in the form of fissure. In terms of time, due to the lag of filling operation and overburden movement, deep overburden fracture lags behind mining process in time. During the process of filling mining, the overburden strata are mainly bent and subsided, and there is no obvious separation between the direct roof and the basic roof. In the vertical direction, the direct roof within $2 \mathrm{~m}$ distance from the coal seam appears to be fractured and cracks are developed, but the integrity is good, and the basic roof does not appear to be fractured. This indicates that, in the process of solid filling 


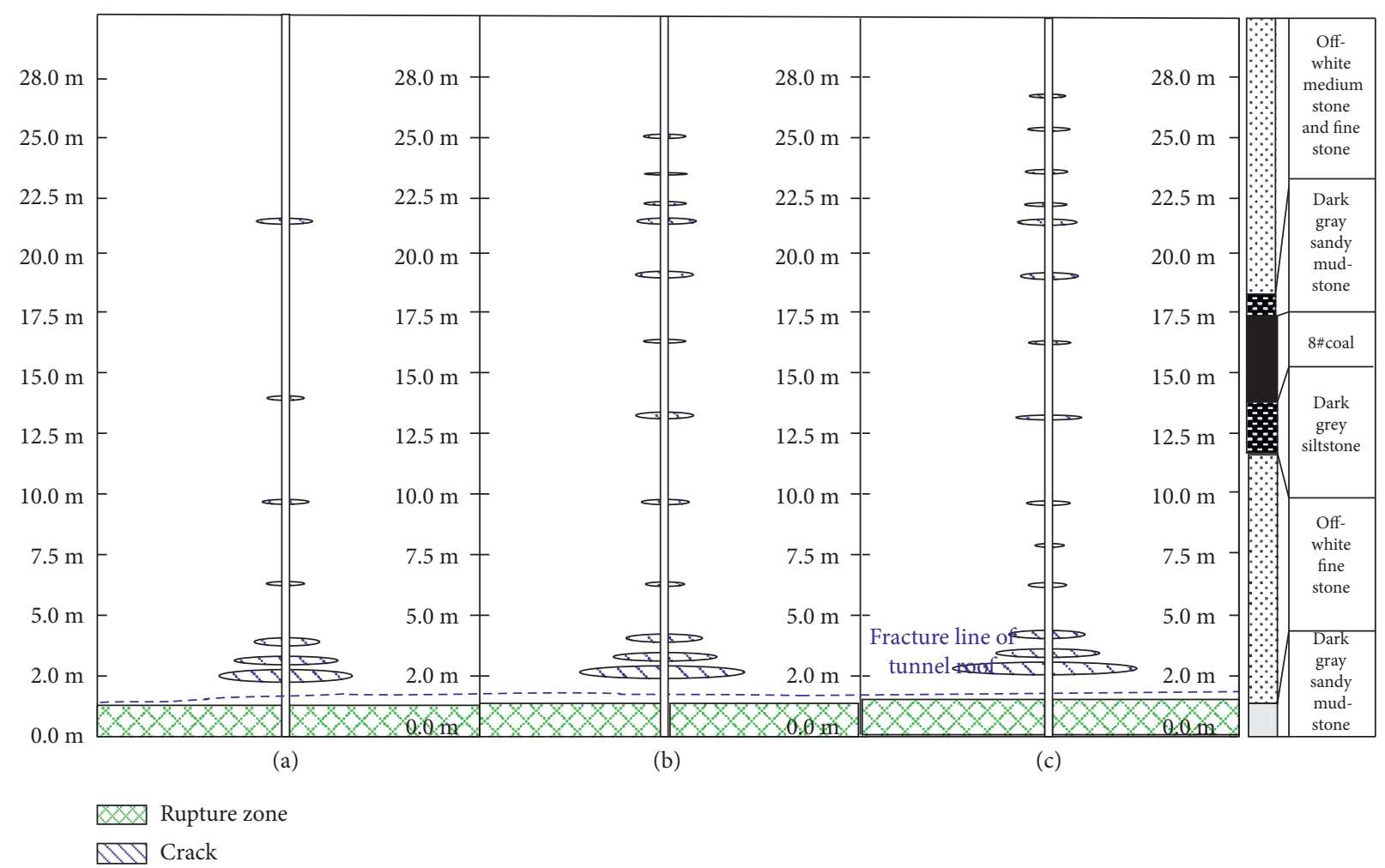

FIGURE 16: Fracture evolution of overburden strata with advancement of mining face.

mining, the direct roof is locally fractured. There was no collapse zone, but the main roof was bending and sinking, and no breakage occurred.

The supporting resistance of hydraulic support in backfilling mining of 8103 working face, the surrounding rock of working face, the change of internal stress in backfilling body, and the crack development of roof are monitored and analyzed. Comprehensive analysis shows that the measured data analysis of 8103 filling face is consistent with the change rule of roof subsidence with the advance of the working face. There is no phenomenon of initial and periodic weighting in the filling mining process. The roof bends and subsides, but no fracture occurs. Monitoring and analysis of roof fracture development characteristics proves that, in the filling process, the direct roof breaks locally without the caving zone, while the basic roof mainly bends and subsides without breaking. The filling body in gob plays an effective role in controlling the movement of overlying strata. With the advancing of the working face, the internal stress of the filling body is gradually stable, which is close to the original rock stress. At this time, the overall bending and subsidence of the overlying strata has become stable under the support of the filling body.

\section{Analysis of Surface Subsidence in Filling Mining Face}

4.1. Layout of Surface Observation Stations and Data Acquisition. In order to solve the problem of safe mining under construction and evaluate the effect of solid filling mining such as gangue, three observation lines (Line 1, Line 2 , and Line 3 ) are set up on the surface of 8103 working face, as shown in Figure 17. The average distance between the observation points is $30 \mathrm{~m}$. Since the working face corresponds to the complex surface buildings and is affected by the topography, it is impossible to establish the coal seam inclination observation line. According to the actual situation of the site, the extension line of the coal seam strike observation line is established, totaling 18 points, with an average distance of $30 \mathrm{~m}$.

Through continuous observation of surface subsidence in 8103 mining face, observation data of line 1 , line 2 , and line 3 are obtained. Fifteen observations of line 1 and line 2 corresponding to 8103 mining face have been made, which lasted 16 months. The observation line No. 3 on the surface of 8103 working face was observed nine times and lasted for 8 months.

4.2. Analysis of Surface Subsidence Data. The subsidence curves along lines 1 to 3 are obtained by processing the observed data of lines 1, 2, and 3, as shown in Figures 18-20. From the graph, it can be seen that the subsidence values of observation points N10-N15 and W4-W7 are on the high side of 8103 working face, and the cumulative maximum subsidence value of observation point N15 is $-38 \mathrm{~mm}$. The actual measurement shows that the mining of 8103 working face has little influence on the surface.

4.3. Prediction Methods and Determination of Parameters. The probability integral method is used to predict surface subsidence in 8103 working face. When the probability 


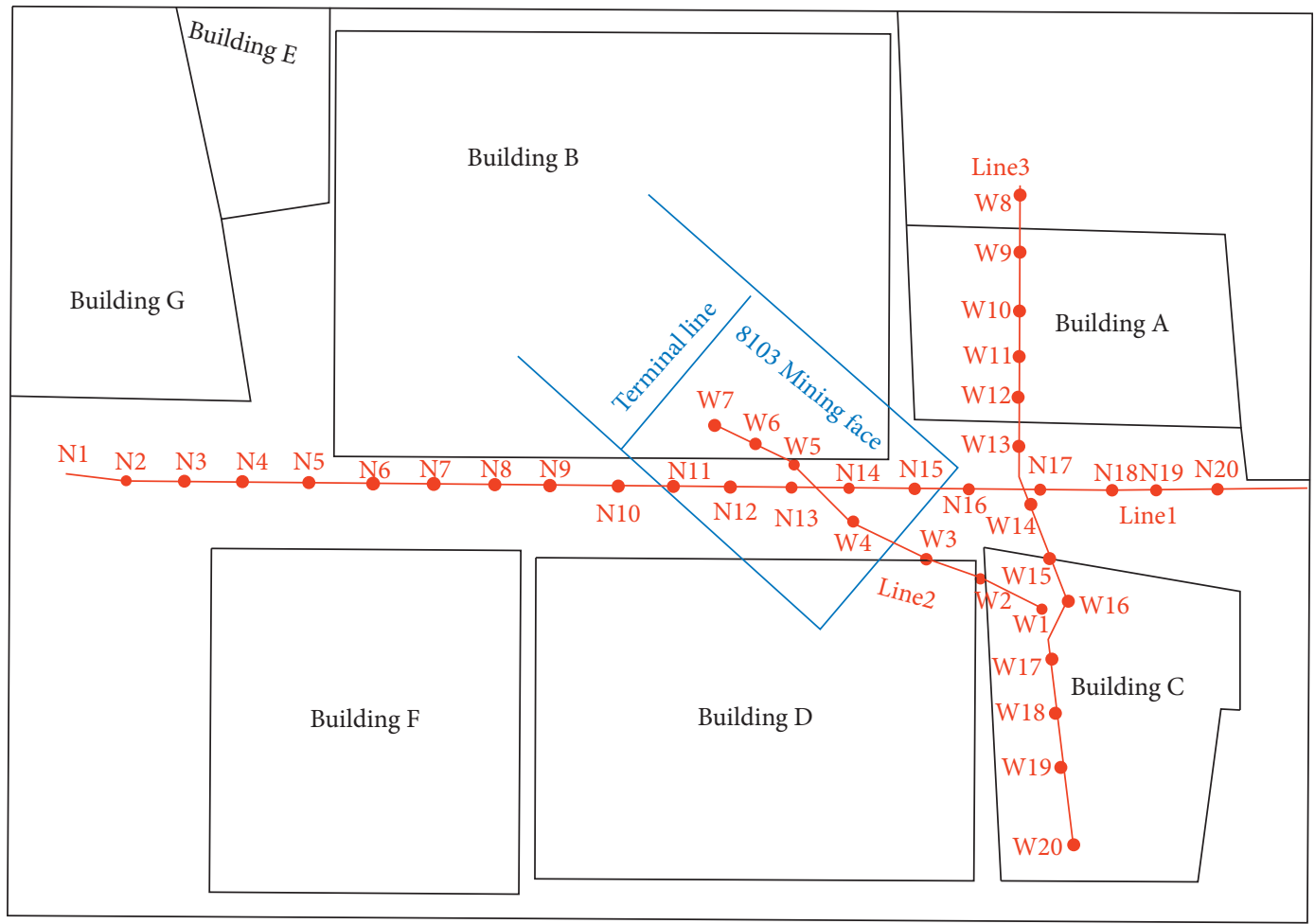

FIGURE 17: Layout of surface subsidence observation station in 8103 working face.

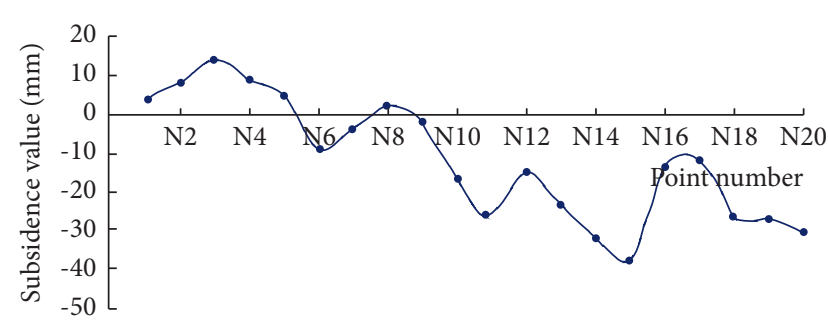

FIgURE 18: Subsidence curve of line 1.

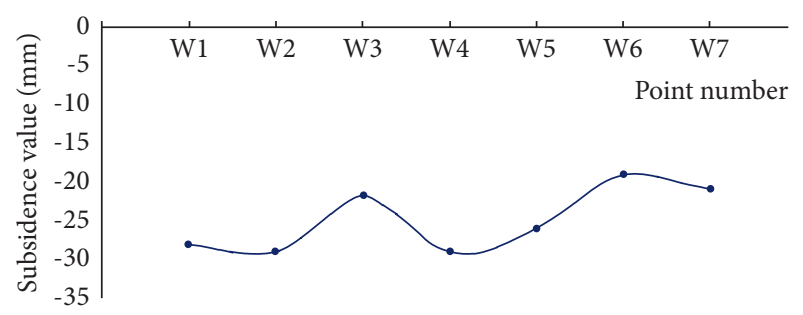

FIGURE 19: Subsidence curve of line 2.

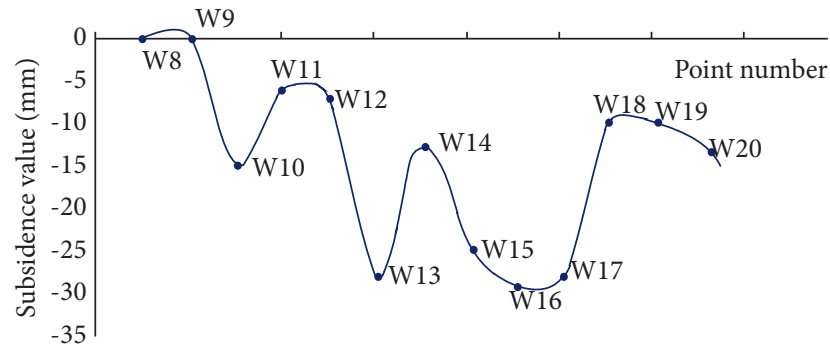

Figure 20: Subsidence curve of line 3. integral method based on equivalent mining thickness is used to predict the surface subsidence of solid filling mining such as gangue, the corresponding parameters of caving mining in this mining area are selected. According to the regularity and parameters of strata and surface movement, the prediction parameters of mining subsidence are listed in Table 1.

The filling mining of 8103 working face is a new type of comprehensive mechanized gangue filling mining system, which can ensure the full contact between the gangue filling body and the roof, that is, the underfilling roof quantity $\mathrm{hq}=0$. In filling mining, the actual mining height minus the height of filling material is equivalent mining height [22], and then, the movement and deformation characteristics of overburden rock in stope can be analyzed by the traditional theory of strata control in nonfilling mining. According to the equivalent mining height theory, the equivalent mining thickness $\mathrm{HD}$ of solid filling mining such as gangue can be expressed as

$$
h_{d}=\frac{\eta h_{m} L_{0}}{L_{0}-(1-\eta) L},
$$

where $L$ denotes roof control distance of the filling face, $m$, $L_{0}$ denotes limit span of the roof, $m, h_{m}$ denotes actual mining thickness of coal seam, $m$, and $\eta$ is compressibility of backfill.

According to the compression test of waste rock in laboratory, $\eta$, compressibility of backfill, is chosen to be equal to $15 \%$. According to the geological and mining data of the strata in the mining area, it is known that the maximum roof control distance $L=9.3 \mathrm{~m}$, limit span of roof $L_{0}=30 \mathrm{~m}$, and actual mining thickness of coal seam $h_{m}=3.5 \mathrm{~m}$. From 
TABLe 1: Prediction parameters of mining subsidence.

\begin{tabular}{lcccc}
\hline Subsidence coefficient & $\begin{array}{c}\text { Horizontal mobility } \\
\text { coefficient }\end{array}$ & $\begin{array}{c}\text { Tangent of main influence } \\
\text { angle }\end{array}$ & $\begin{array}{c}\text { Propagation angle of mining } \\
\text { influence }\end{array}$ & $\begin{array}{c}\text { Inflection point } \\
\text { offset }\end{array}$ \\
\hline 0.74 & 0.35 & 1.8 & $\theta_{0}=88^{\circ}$ & 0 \\
\hline
\end{tabular}

TABle 2: Prediction of maximum surface movement and deformation in 8103 filling mining face.

\begin{tabular}{|c|c|c|c|c|c|c|c|}
\hline \multirow[t]{2}{*}{ Direction } & \multirow[t]{2}{*}{ Surface subsidence $(\mathrm{mm})$} & \multirow[t]{2}{*}{ Horizontal movement $(\mathrm{mm})$} & \multicolumn{2}{|c|}{$\begin{array}{c}\text { Horizontal } \\
\text { deformation }(\mathrm{mm} / \mathrm{m})\end{array}$} & \multicolumn{2}{|c|}{$\begin{array}{l}\text { Curvature } \\
(\mathrm{mm} / \mathrm{m} 2)\end{array}$} & \multirow[t]{2}{*}{ Tilt deformation $(\mathrm{mm} / \mathrm{m})$} \\
\hline & & & Stretch & Compression & Plus & Minus & \\
\hline Strike & \multirow{2}{*}{65} & 32 & 0.14 & -0.30 & 0 & 0 & 0.2 \\
\hline Dip & & 33 & 0.14 & -0.32 & 0 & 0 & 0.2 \\
\hline
\end{tabular}



FIGURE 21: Forecast contour of surface subsidence in 8103 backfilling mining.

formula (1), the equivalent mining thickness $h_{d}$ of filling mining in 8103 working face is $0.713 \mathrm{~m}$.

4.4. Prediction and Analysis of Surface Subsidence. This paper calculates the surface subsidence caused by filling mining in 8103 working face with the method of outline integral and obtains the maximum predicted value of surface movement and deformation, as listed in Table 2. The prediction contours of surface subsidence, horizontal movement, and horizontal deformation along strike and dip directions in filling mining of 8103 working face are obtained, as shown in Figures 21-25.
Since the compaction process of filling material in 8103 working face is gradual, the stability time of surface subsidence in filling mining is generally 3-6 months, and the prediction result of surface subsidence is the final subsidence value, so the prediction value of surface subsidence is larger than the observation value. For example, the predicted maximum subsidence $(65 \mathrm{~mm})$ is larger than the observed maximum subsidence $(38 \mathrm{~mm})$.

After filling mining in 8103 working face, the predicted value of maximum subsidence is $65 \mathrm{~mm}$, the predicted value of maximum inclination is $0.2 \mathrm{~mm} / \mathrm{m}$, and the predicted value of maximum horizontal deformation is $0.32 \mathrm{~mm} / \mathrm{m}$, which has little impact on the surface and buildings. 


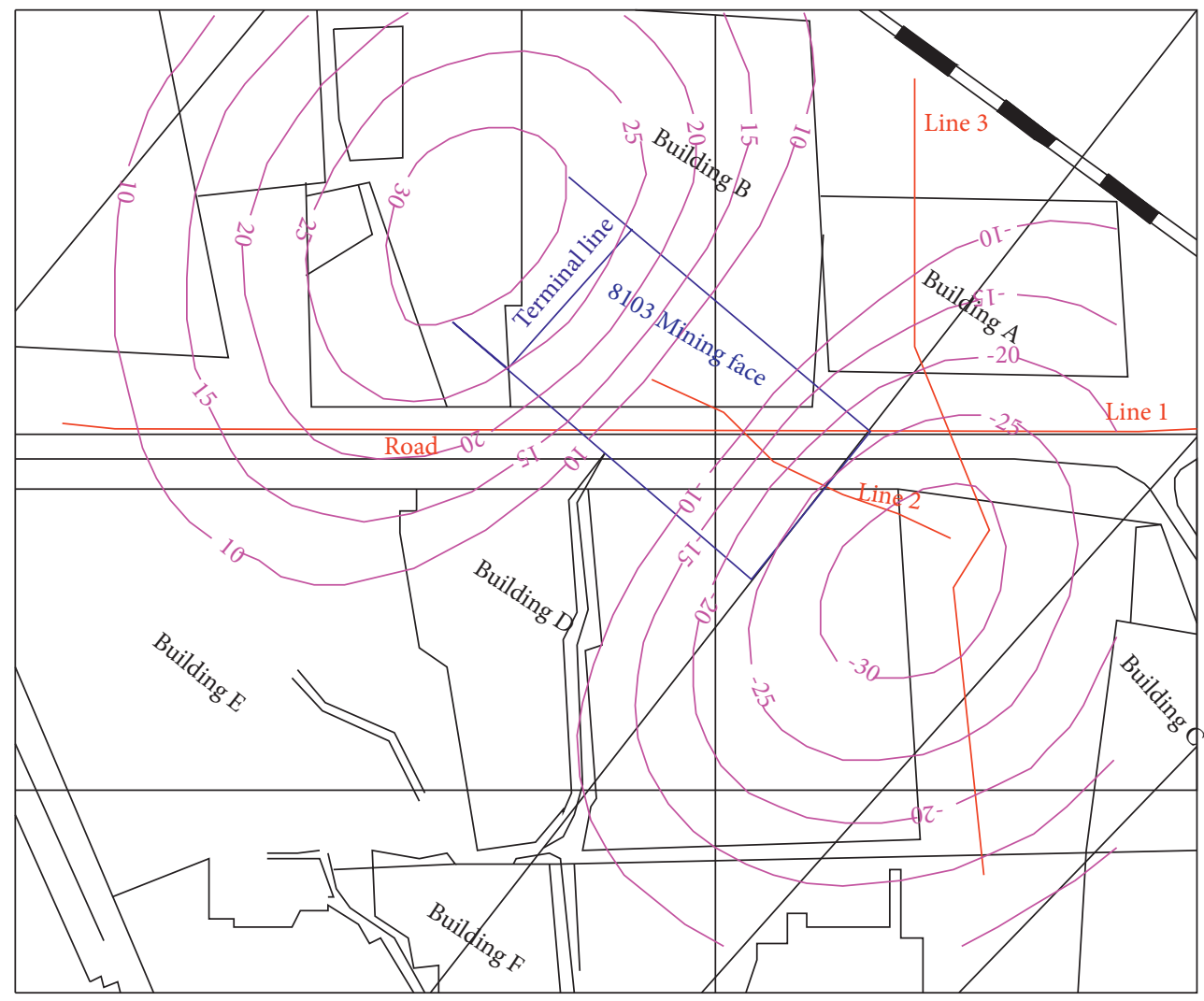

FIgURE 22: Forecast contour of surface horizontal movement along strike in 8103 backfilling mining.

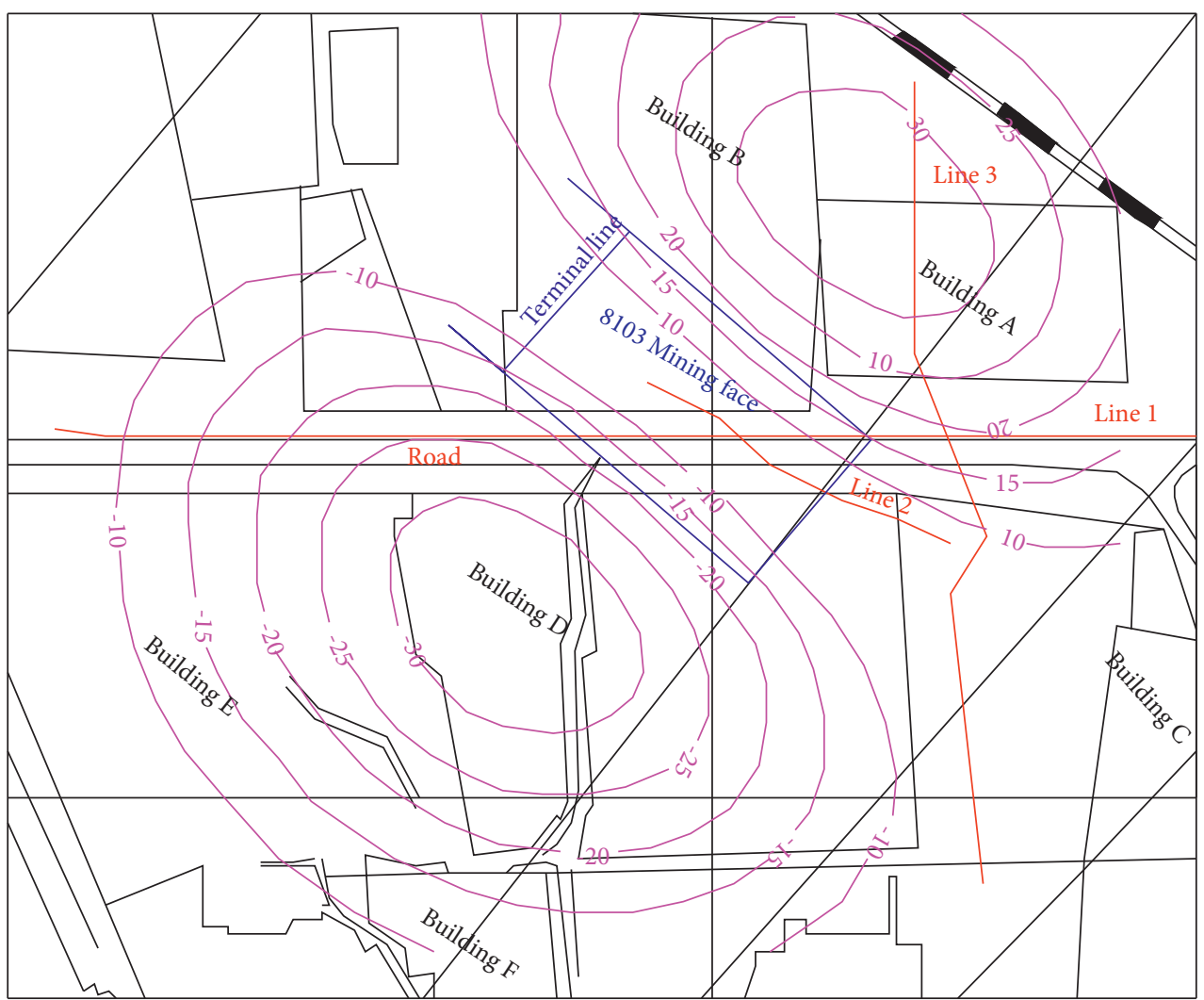

FIgURE 23: Forecast contour of surface horizontal movement along inclination in 8103 backfilling mining. 


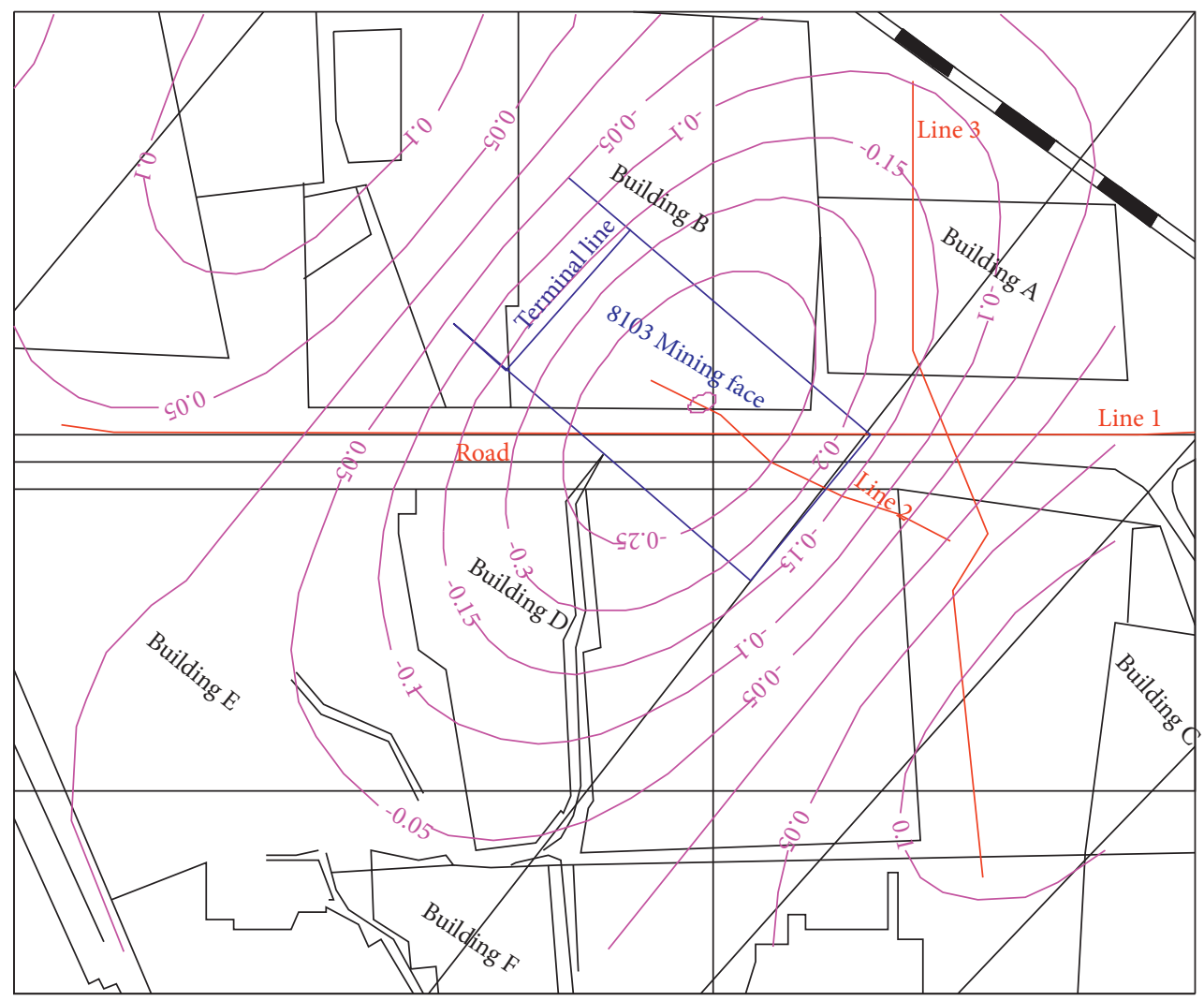

FIGURE 24: Forecast contour of surface horizontal deformation along strike in 8103 backfilling mining.



Figure 25: Forecast contour of surface horizontal deformation along inclination in 8103 backfilling mining. 


\section{Conclusions}

This study reveals the characteristics of rock pressure in solid filling mining face. The average working resistance of the support does not reach the rated working resistance of the hydraulic support of $8800 \mathrm{KN}$, and there is no sharp increase in working resistance. The stress variation law of filling body can be divided into three stages: initial stress zone, stress increasing zone, and stress stable zone without stress surge. This shows that there are no initial and periodic weighting phenomena in the mining process of filling coal face.

It reveals the evolution characteristics of overburden fracture in solid filling mining. The overburden morphology in solid filling mining is mainly characterized by the bending zone and the fracture zone with certain height, without the caving zone. In the process of solid filling mining, the direct roof is broken locally without the caving zone, while the basic roof is mainly bending subsidence without breaking.

The research shows that the probabilistic integral method model based on equivalent mining thickness is unified, and the surface subsidence of 8103 working face is effectively predicted by the probabilistic integral method. In order to make full use of the observation results of surface movement in caving mining, it is suggested that the probabilistic integral model should be used to predict surface subsidence in solid filling mining. Furthermore, a method of selecting parameters system of the probability integral model based on equivalent mining height is proposed.

\section{Data Availability}

The data used to support the findings of this study are included within the article.

\section{Conflicts of Interest}

The authors declare that they have no conflicts of interest.

\section{References}

[1] Y. X. Liu, "Underground gangue backfilling technique and surface reducing-subsidence effectiveness in coal mine," Safety In Coal Mines, vol. 49, no. 4, pp. 205-207+211, 2018.

[2] X. X. Miao and M. G. Qian, "Research on green mining of coal resources in China: current status and future prospects," Journal of Mining \& Safety Engineering, vol. 26, no. 1, pp. 1-14, 2009.

[3] M. G. Qian, X. X. Miao, and J. L. Xu, "Green mining of coal resources harmonizing with environment," Journal of China Coal Society, vol. 32, no. 1, pp. 1-7, 2007.

[4] C. X. Wang, Experimental Study on Mining Effect and Gangue Pillar Stability of Cutting Backfilling Mining Method, Shandong University of Science and Technology, Qingdao, China, 2020.

[5] Z. Wang, W. Zhou, T. Shu, Q. Xue, R. Zhang, and M. Wiercigroch, "Modelling of low-frequency acoustic wave propagation in dilute gas-bubbly liquids," International Journal of Mechanical Sciences, 2021.

[6] M. Li, Mechanical Behaviour of Gangue Backfill Material and Control Mechanism of Strata Movement, China University of Mining and Technology, Xuzhou, China, 2018.
[7] W. Yin, X. Bao, H. F. Liu et al., "Research on overlying strata structure and ground control in transition area of fully mechanized mining working face," Journal of Mining \& Safety Engineering, vol. 35, no. 1, pp. 86-93, 2018.

[8] G. Yang, Y. Hang, J. Zhang et al., "Study on overburden failure numerical simulation in paste-like material backfill mining," Coal Geology of China, vol. 33, no. S1, pp. 56-60, 2021.

[9] J. X. Zhang, J. Li, T. L. An, and Y.-L. Huang, "Deformation characteristic of key stratum overburden by raw waste backfilling with fully-mechanized coal mining technology," Journal of China Coal Society, vol. 35, no. 3, pp. 357-362, 2010.

[10] Q. D. Qu, Q. L. Yao, X. H. Li, and T.-Y. Rong, "Key factors affecting control surface subsidence in backfilling mining," Journal of Mining \& Safety Engineering, vol. 27, no. 4, 2010.

[11] B. Z. Yao, "Underground gangue backfilling technique and surface reducing-subsidence effectiveness in coal mine," Safety In Coal Mines, vol. 43, no. 6, pp. 47-49, 2012.

[12] J. X. Zhang, X. X. Miao, and G. L. Guo, "Development status of backfilling technology using raw waste in coal mining," Journal of Mining \& Safety Engineering, vol. 26, no. 4, pp. 395-401, 2009.

[13] C. Y. Liu, P. J. Yang, C. J. Hou et al., "Movement law and stability analysis of overlaying strata under the condition of mining with filling," Journal of China University of Mining \& Technology, vol. 33, no. 2, 2004.

[14] J. F. Sun, W. Q. Zhang, H. Yan et al., "Study on behavior law of ground pressure of the solid backfilling mining in tangkou kilometers deep mine," Mining Research and Development, vol. 38 , no. 11 , pp. $40-45,2018$

[15] W. J. Tang, X. K. Sun, H. Wang et al., "Study on effect of overlying strata stability during strip coal pillar excavation with paste backfilling," Coal Science and Technology, vol. 45, no. 9, pp. 109-115, 2017.

[16] H. Z. Wang, Study on Fracture Mechanism of Surface Borehole and Inversion of Overburden Movement in Response to Underground Mining, China University of Mining and Technology, Xuzhou, China, 2018.

[17] B. J. Yin, A. L. Wang, P. F. Zhang et al., "Analysis of the laws and control effect of surface subsidence of solid backfilling mining," China Coal, vol. 44, no. 10, pp. 81-86, 2018.

[18] Q. Yao, F. Tao, and Z. Liao, "Damage characteristics and movement of inclined strata with sublevel filling along the strike in the steep seam," Journal of China Coal Society, vol. 42, no. 12, pp. 3096-3105, 2017.

[19] H. Zhu, F. He, and Y. Fan, "Development mechanism of mining-induced ground fissure for shallow burial coal seam in the mountains area of southwestern China: a case study," Acta Geodynamica et Geomaterialia, vol. 15, no. 4, pp. 349-362, 2018.

[20] J. Blachowski, E. Jiránková, M. Lazecký, P. Kadlečík, and W. Milczarek, "Application of satellite radar interferometry (PSInSAR) in analysis of secondary surface deformations in mining areas case studies from Czech Republic and Poland," Acta Geodynamica et Geomaterialia, vol. 15, no. 2, pp. 173185, 2018.

[21] W. Gruszczynski, Z. Niedojadlo, and D. Mrochen, "Influence of model parameter uncerainties on forecasted subsidence," Acta Geodynamica et Geomaterialia, vol. 15, no. 3, pp. 211-228, 2018.

[22] Z. P. Cui, "Subsidence prediction of mining with filling based on probability integral principle of equivalent mining height," China Coal, vol. 42, no. 6, pp. 63-66, 2016. 